\title{
Why is the Geisha Hitting the Westerner? The Japanese Woodblock Print Genre of awate-e
}

\author{
Hannah Nowak
}

\begin{abstract}
This paper attempts to bring to light a little-known genre of ukiyo-e (Japanese woodblock prints), the awate-e (hysteria pictures). This genre of polychrome ukiyo-e (nishiki-e) belongs among caricatures because it treats current events in a satirical way. The Namamugi incident (September 14, 1862), when samurai of the Satsuma domain killed one British merchant and injured two, led to the emergence of the awate-e. The British Crown demanded reparations for those killed. While the shogunate postponed payment, British warships gathered in the Bay of Edo to exert pressure. The danger of war was real and the cities of Yokohama and Edo were considered the main targets of a British attack. Many people moved to rural areas or at least sent their families and belongings away. This led to an increased demand for transport, houses, and land in the countryside. Hardly anybody remaining in the cities spent time in the pleasure quarters or bought luxury goods. The results were dramatic for people in those trades. This situation is satirised in the awate-e. Starting with the question 'Why is the Geisha hitting the Westerner?', this paper explores the genre of awate-e and its relevance for historical and ukiyo-e research by studying 21 awate-e as primary sources. It reveals a negative appraisal of Westerners, of people leaving the danger zone, and of professions in high demand. The producers of awate-e are biased towards people staying in areas become dangerous, professions suddenly grown poor, and the foreigners-out policy of the Emperor.
\end{abstract}

Keywords: awate-e, Edo, hysteria pictures, Namamugi incident, nishiki-e

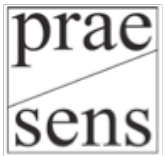

Nowak, Hannah. "Why is the Geisha Hitting the Westerner? The Japanese Woodblock Print Genre of awate-e." In Vienna Journal of East Asian Studies, Volume 5, eds. Rudiger Frank, Ina Hein, Lukas Pokorny and Agnes Schick-Chen. Vienna: Praesens Verlag, 2014, pp. 139-170. https://doi.org/10.2478/vjeas-2014-0006 


\section{Introduction}

This paper was written as part of the Austrian Science Fund project 'Ukiyo'e Caricatures 1842-1905' at the Department of East Asian Studies (Japanese Studies) of the University of Vienna. Sepp Linhart, leader of this project, brought the woodblock print 浮世絵 (ukiyo-e) genre called awate-e (あわて絵 or 慌て絵 or 周章絵 ; 'hysteria pictures') to my attention. I was fascinated by this widely ignored genre and its telling of a little-known event in Japanese history.

Figure 1 Why is the Geisha hitting the Westerner? (detail)

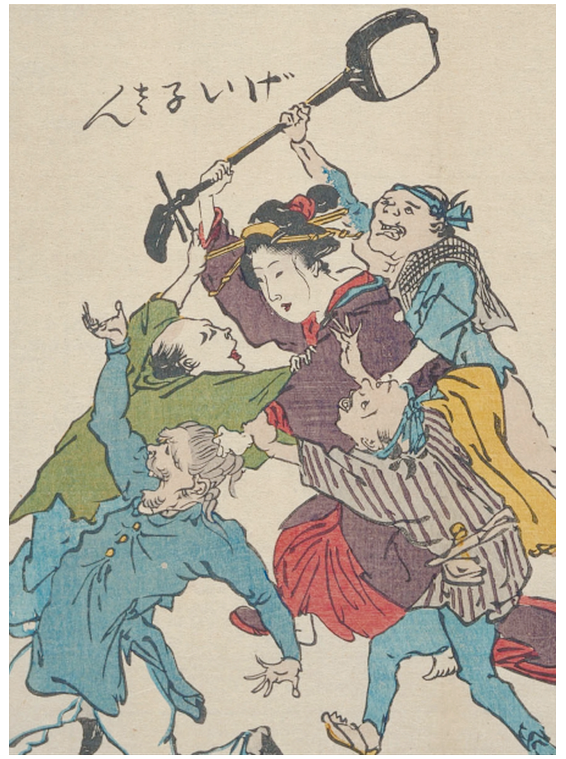

Source: Waseda University Library ${ }^{1}$

Questions to be answered in this paper are: What are awate-e? How can they be recognised? What do awate-e show about Japanese history? Are they partial? And last but not least: why is the Geisha hitting the Westerner (see figure 1, detail, of the awate-e named Töji seisui kurabe 当時盛衰競; Comparison of Current Fates)?

The Namamugi incident (Namamugi jiken 生麦事件), trigger of the events that are shown in awate-e, is a well-documented episode in Japanese history books. There are also reports by contemporary British witnesses, such as the diplomat and scientist Ernest Satow (1843-1929; A Diplomat in Japan) and John Reddie Black (1826-1880; Young Japan). But the turmoil in Edo, the looming war between Great Britain and Japan in spring 1863, coming between the Namamugi incident and the Anglo-Satsuma War Satsuei-sensō 薩英戦争 (British attack on Kagoshima 鹿児島,

1 The images used in this paper are reproduced with permission of the respective institutions. 
the capital of the Satsuma-han 薩摩藩), is omitted from most texts on Japanese history (see Matsumoto 1998, Nihon Kindaishi Kenkyūkai 1989). Only ukiyo-e researchers and the eyewitness Ernest Satow mention these events. That the war never broke out may be the reason why the situation in the threatened areas and the genre of awate-e depicting it have been almost forgotten.

Much has been written about ukiyo-e, but awate-e are mostly left out. Even in several ukiyo-e lexica the genre is missing; see, for instance, the Genshoku Ukiyo-e Daihyakka Jiten 原色浮世絵大百科事典 (Great Encyclopedia of Woodblock Prints in Colour) from 1980 (Genshoku ukiyo-e daihyakka jiten henshū iinkai 1980), and Newland 2005. Only the International Ukiyo-e Society (2008) contains a definition in its publication, the Ukiyo-e Daijiten 浮世絵大辞典 (Great Encyclopedia of Woodblock Prints). Researchers who treat awate-e in their work are Katō Mitsuo 加 藤光男 (2004), Minami Kazuo 南和男 (1999) and Nagura Tetsuzō 奈倉哲三 (2007), though only as a short digression from their main topics.

The Machida City Museum, the Historiographical Institute of the University of Tōkyō (HIUT) and Waseda University own the greatest number of awate-e. Most of the pictures in this paper are from HIUT. Though it does not own awate-e themselves, the most informative source with transcriptions and some translations is the nishiki-e Caricature Database of the University of Vienna (WDB 2006).

This study analysed 21 awate-e that were found during the research. The literature does not contain any figure for how many awate-e were originally created or remain today, but we can assume that many more were published but have been lost and also that some more prints survive undiscovered in archives.

Five of the analysed pictures are diptychs, printed on two sheets (ni-mai-tsuzuki 二枚続), and 16 are printed on one sheet. All one-sheet pictures are printed in portrait format; the diptychs are printed in horizontal format, consisting of two portrait format sheets. Of the 21 , four representative prints were selected for this paper. The others can be found in the WDB or in the original study (see Nowak 2010). The analysis of the pictures follows the method created by Nagura (2007), who uses woodblock prints as a source of information about the time of their creation.

All awate-e were translated by the author (except for a few unreadable parts caused by the bad quality of printing or frayed borders), the complete translation can be found in German in my previous research (Nowak 2010).

\section{What are awate-e?}

The definition of awate-e in the Ukiyo-e Daijiten of the International Ukiyo-e Society is as follows: 
In the Year Bunkyū 2, as the jōi movement, advocating the seclusion of the country and the termination of relations with foreign countries, grew increasingly powerful, four British citizens, who had crossed the path of the retinue of Shimazu near Namamugi in Kanagawa without dismounting from their horses, were injured or killed. Great Britain consequently demanded reparations from the shogunate, which could not prevent the murdering of Westerners. To support these demands, many foreign ships congregated in the Bay of Edo as intimidation. Because of this upheaval the rumour developed that Edo and Yokohama would be attacked from the harbour, and several people packed their possessions hastily and moved away. There was a commotion, since among others baggage transporters suddenly had a lot of work, and in contrast geishas, among others, suddenly had very little work. ... Since they are reports or caricatures of actual events, they do not have a signature (International Ukiyo-e Society 2008: 16).

Awate-e are Japanese woodblock prints, ukiyo-e in Japanese, more specifically multi-coloured woodblock prints, known as nishiki-e 錦絵 ('brocade pictures'). They belong to the category of füshiga 風刺画 (caricatures), since they satirise current events. They spread news and were therefore illegal. They show scenes of the situation in Edo 江戸 (today's Tōkyō) and Yokohama in the third and fourth months of the year Bunkyū 3 (mid-April to mid-June 1863).

Awate-e are one of the nishiki-e genres which are "not in high regard worldwide, since they emerged in the so-called 'decline of ukiyo-e' and are therefore missing in most collections" (Linhart 1998: 196-197). Awate-e indeed sport less detail, colours and precision than many older ukiyo-e prints.

As mentioned in the passage quoted above, signature, publisher's mark and date seal are missing in awate-e, but this applies to many other genres of the Bakumatsu era 幕末 ('End of the Shogunate', 1853-1878). One awate-e with publisher's mark and date seal has been found (the print Ukiyo yume hanashi, see Yuasa 1995: 76). Still, the majority of awate-e seems to have been published illegally. Despite, or probably partly because of, their recalcitrant nature, there was an audience for these prints large enough to support a füshiga genre for every major event between the appearance of the namazu-e (earthquake pictures) in 1855 and their disappearance with the arrival of newspapers.

Awate-e are a news medium, but with the primary goal of entertaining, not informing. At the time of awate-e there existed the kawaraban 瓦版 for news. These prints, mostly black and white, gave information on recent events as quickly as possible (see, e.g., Linhart 2005a and Groemer 1994). 


\section{Socio-political background}

\section{The socio-political situation in Japan at the time of the awate-e}

The Bakumatsu, the last decade of the Tokugawa shogunate, started with the arrival of the 'black ships' in 1853 and ended with the Meiji Restoration (meiji ishin 明治 維新) in 1867. Under the Sakoku 鎖国 policy, from the beginning of the 17th until the middle of the 19th century, Japan limited contact and trade with the outside world. It had contact via the trading city of Nagasaki with several Asian countries and the Netherlands. Japan was well informed about the goings-on in the world, thanks to imported books and other articles (Linhart 2004: 43-44). Edo (today's Tōkyō) was the seat of the shogunate and therefore the political, economic and cultural capital.

Though there existed an emperor (Tennō 天皇) with a court in Kyōto, he had little political influence. Japan was divided into domains (han 藩), which officially belonged to the Tennō (in reality to the Shōgun 将軍). They were in the hands of the same regional ruling families for generations, who were able to manage their han quite freely. The chief of a domain was called the daimyo 大名. In the 1830s and 1840s some han started to question openly the government of the Shōgun. In this tumultuous time, in 1853, Commodore Matthew Calbraith Perry (1794-1858) arrived and demanded the opening-up of trade. The Satsuma han was one of the most powerful domains in Japan at the time and involved in the Namamugi incident.

\section{The Namamugi incident and its repercussions}

The Namamugi incident is named after the scene of the event, the village of Namamugi, today part of the Tsurumi district 鶴見区 of Yokohama. The cities of Yokohama 横浜and Edo both lie on the Bay of Edo, but only Yokohama harbour was open to foreigners. Foreign merchants and diplomats resided there. Since the opening-up of the harbour, there had been several attacks on Western foreigners. The most recent attacks before the Namamugi incident were the first (May 28, 1861) and second Tōzenji incidents (May 29, 1862; Hashimoto 1987: 78).

In September of 1862 (Bunkyū 2, 8th month), Shimazu Hisamitsu 島津久光, an 'advocate of anti-foreignism' (Brandl 2009: 68; see also Konishi 1977: 132) and the father and regent of the daimyō of the Satsuma han (Shimazu Tadayoshi 島津忠義) travelled with many retainers from Edo to Kyōto (Nihon Kindaishi Kenkyūkai 1989: 76). On September 14, 1862 (Bunkyū 2, 8th month, 21st day), the British merchant Charles Lennox Richardson (1834-1862) was in Japan for sightseeing. Accompanied by his friends Woodthorpe Charles Clark and William Marshall as well as 
Marshall's sister-in-law Margaret Watson Borrodaile, he set out from Yokohama to Kawasaki (Hashimoto 1987: 69), to visit a temple (Black 1968: 126).

Near Namamugi the parties met. The Satsuma vanguard tried to get the British to dismount to show respect to the daimyō, but they refused. Therefore the samurai attacked the Westerners (Nihon Kindaishi Kenkyūkai 1989: 76; Konishi 1977: 133). Black gives a vivid and detailed account of the incident (see Black 1968: 130-138). Richardson was killed (see Hashimoto 1987: 79; Black 1968: 138). The Namamugi incident is thus also called the 'Richardson affair' or 'Richardson episode' in English-language sources.

The British chargé d'affaires Edward St. John Neale (1812-1866) restrained his countrymen residing in Japan from seeking revenge, afraid that they would trigger the looming war between Great Britain and Japan (Black 1968: 139). On the 19th day of the 2nd month of Bunkyū 3 (April 9, 1863), Neale demanded reparations of 110,000 pounds from the Shōgun (Nihon Kindaishi Kenkyūkai 1989: 76) and 25,000 pounds and the capture of Richardson's killer from the Satsuma domain. To support these demands, twelve British warships gathered in the harbour of Yokohama (Minami 1999: 58-59). The rumour emerged that Edo and Yokohama would be attacked from the harbour.

The Japanese government delayed a decision on whether and when it would pay with several excuses and requests for revision, keeping people in fear of attack. This produced the situation caricatured in awate-e. The reparations reached the British legation in Yokohama on June 24, 1863 (Bunkyū 3, 5th month, 9th day). Satsuma did not pay until British warships attacked its capital (see Nihon Kindaishi Kenkyūkai 1989: 76; Black 1968: 223-231) in the Anglo-Satsuma War.

\section{Effects on the people of Yokohama and Edo}

\section{Fear of attack and preparations for war}

The time-span between the demand for reparations and their payment, between the end of the 2nd month and the beginning of the 5th month of Bunkyū 3 (between the beginning of April and the end of June 1863), was one of turmoil for the people living on the Bay of Edo.

The shogunate started preparations for war. People in the endangered areas began to transport their families and belongings further inland. The whole population of the small harbour town of Uraga 浦賀 at the entrance to the Bay of Edo moved to Hodogaya 保土ケ谷. Satow names April 20 as the start of people leaving Edo (Satow 2003: 67). On the 4th day of the 3rd month (April 21), the shogunate ordered the eight han in the Edo region to 'prepare according to the circumstances' (Minami 
1999: 58), meaning prepare for war. The next day a machibure 町触 (bulletin to the city population) was issued, which gave the citizens the same information. Daimyo families could return home, and old or sick people, women and children in these areas should flee further inland (see Katō 2004: 124; Minami 1999: 58-59; Nagura 2007: 18). With this bulletin, for the first time in history the shogunate directly warned the people of Japan of a danger to the state (Nagura 2007: 18).

On May 1, the shogunate requested another delay of 15 days. People's fear grew and many shop owners in Yokohama and surrounding areas moved to Hodogaya. All farmers within two miles of Yokohama were ordered to prepare to surrender their houses to troops (Satow 2003: 67).

In the night of May 5 there was an exodus of Japanese domestic servants from the foreigners' quarter. All the following day Japanese people left Yokohama in droves. Satow tells of seeing many empty houses and great tension between Japanese and Westerners (Satow 2003: 68-69).

On May 16, the shogunate told Neale that the return of the Shōgun was uncertain (Satow 2003: 70), delaying the reparations indefinitely. After Neale threatened with war, a payment in inconspicuous instalments was decided on May 25 (Satow 2003: 71-73). At the beginning of June, the rumours about war preparations had died down (Satow 2003: 73). From that moment on, people probably started to return. The reparations were finally paid on June 24 (Satow 2003: 74).

\section{The economic effects of the flight}

Leaving the endangered areas was a great financial burden. Especially for the Edokko 江戸っ子 ('children of Edo', people who had lived in Edo for several generations; see, e.g., Schwan 2003: 34-35), who had no relatives in the countryside, the decision was a hard one. All transport-related trades (International Ukiyo-e Society 2008: 16) - luggage-carriers, sedan-bearers, pack horse leaders, carters and boatmen-but also farmers, inn owners on travel routes, and of course owners of land and buildings out in the country profited from the situation (see picture analyses as well as, e.g., Minami 1999: 60). Because of the high demand, these groups started charging horrendous prices. Manufacturers of items necessary for moving, such as baskets, long-lasting food and household items, as well as weapon- and armour-makers profited from the exodus, as will become clear in the picture analyses.

The opposite happened to the entertainment industry in the endangered cities. Nobody had time or money to spend on idle activities. Yoshiwara 吉原, the famous pleasure quarter of Edo, suffered a sharp financial decline (International Ukiyo-e Society 2008: 16) and grew virtually deserted, like 'a fire going out' (Minami 1999: 
60). The number of houses for sale in the city rose rapidly and the credit business and pawnbroking trade collapsed (Minami 1999: 60).

\section{Recognising awate-e}

At around the time of awate-e, another genre developed, of which some prints show similar scenes and therefore can be easily mistaken for awate-e and vice versa. These woodblock prints are called boshin-senso-e 戊辰戦争絵 ('pictures of the Boshin War' 1868 to 1869; for more on the genre see, e.g., Nagura 2007). Since the effects of this civil war on the population were quite similar to the effects of the British warships in the harbour, some boshin sensō-e show the same trades as winners and losers as in awate-e. These pictures often cannot be reliably classified (see Yuasa 1995: 76).

The following collection of characteristics of awate-e is intended to give a framework for the picture analyses as well as help to identify awate-e. Since awate-e belong to the nishiki-e, they are multi-coloured. The design of an awate-e is defined by its simplicity and comparatively large areas of one colour without patterns. Often there is no detailed background but only a so-called bokashi ぼかし (a fading colour gradient of one colour, often blue). The design's complete creativity is focused on the entertaining content. Facial expressions are distinct and the recognisability of the characters in the pictures is a priority. To ensure this, clothes are decorated with characteristic items and canonical tools are put into the hands of the characters.

Written text is an important component of awate-e and therefore helps to distinguish them, even if the title is the only text. For example, the text could mention the situation at the time: people leaving Edo, geishas having no clients, and luggagecarriers earning heaps of money because of the Westerners. But even without reading the whole text, keywords can help to identify the genre:

One would assume the word awate to appear frequently, but of all 21 analysed prints, only two contain this word. The reason could be that most pictures do not show the flight itself but the after-effects of the flight.

Ukiyo 浮世 (floating world) is an important concept for Japanese woodblock prints in general. Ukiyo is the "world of sensual pleasures..., the world of the theatres and pleasure quarters, the "world of festivals and extravagant luxury" (Schwan 2003: 89). In the golden age of ukiyo-e, pictures of the floating world, their main themes were courtesans and actors, people of the ukiyo. In awate-e, the ukiyo, meaning both abstractly the world of sensual pleasures and specifically the pleasure quarters in Edo, is threatened, and people are looking for a new 'floating world' in the country. 
Dokyō 度胸 ('courage'; in awate-e mostly どきやう) is an important topic of awate-e. Sometimes only implied by the picture, sometimes part of the text, 'courage' is in demand. The citizens in the endangered areas want the government to act courageously against the British; the economic losers want their fleeing clients to have more courage and stay.

\section{Personified concepts in awate-e}

A characteristic of awate-e is that they depict persons who, with their actions and facial expressions, represent the economic situation of their trade at the time. They are of course personified concepts, stereotypes, as imagined by their designers in 1863.

Most frequently the luggage-carrier appears, recognisable by his pole with a baggage net at the end. Being in the transport business, he was one of the major profiteers of the Namamugi incident and the subsequent events - the flight from Edo to the countryside. He appears on nearly every awate-e and gets selected for those prints even when only up to three trades are shown. The baggage-carrier is mostly in the company of carters, boatmen and horse leaders, as well as land and house owners in the countryside.

The geisha, his main opponent, can be found in nearly all awate-e as well. As one of the few or even the only female character depicted, she is easy to recognise. Sometimes she is accompanied by colleagues from the entertainment industry or money-lenders, pawnbrokers and sellers of luxury goods.

The trades can be recognised by the characters' clothing and the items or animals they have with them. In some pictures a characteristic item may even replace the head of a character. The trades that were on the lucky side are depicted along with the following motifs: luggage, carrier-pole, tsuzura 葛籠 (a big, dark clothing basket), sweatband knotted at the forehead, wheel, cart, coat, paddle, farmer's tools and horse. Sake bottles (in hand, celebrating) and money near people in poor clothes represent sudden good fortune. The trades on the unhappy side can be recognised by the shamisen 三味線, comb, hairpin, fish, mason's trowel, fan, abacus, kitchen knife, pawnbroker's notebook, serving tray and sake bottles (as a pattern on clothing).

The trades are also an important topic in the textual parts of awate-e. They appear in most texts, and in most pictures characters representing trades are marked with the name or an abbreviation of their trade. Tables 1 and 2 below list the trades mentioned in the awate-e covered in this analysis. They are categorised into trades suffering and trades profiting from the exodus from the endangered areas: 
Table 1 Economic losers mentioned in awate-e

\begin{tabular}{|c|c|c|}
\hline \multicolumn{3}{|c|}{ Economic losers mentioned in awate-e } \\
\hline transcription & Japanese & translation \\
\hline anma & あんま & masseur \\
\hline bekkōya & ベつこうや & tortoise-shell carver \\
\hline daiku & 大工 & carpenter \\
\hline Edo no hippari & 江戸のひッぱ里 & street prostitutes in Edo \\
\hline esōshiya & えそうしや & picture-book dealer \\
\hline furoko & ふろこ & bathhouse girl \\
\hline furudōguya & 古道具屋 & junk dealer \\
\hline furugiya & 古ぎや & old clothes dealer \\
\hline geinin & 芸人, げいにん, 藝人 & entertainer \\
\hline geisha, geiko-san & $\begin{array}{l}\text { 藝者, げいしや, げい者, げ } \\
\text { い子さん }\end{array}$ & geisha \\
\hline gofukuya & 呉服屋 & draper \\
\hline haikaishi & はいかいし & haikai poets \\
\hline hanashika & はなしか & story-teller \\
\hline horimonoshi & ほりものし & wood-carver \\
\hline kaiseki chaya & 会席茶や & $\begin{array}{l}\text { owner of a tea house for celebra- } \\
\text { tions }\end{array}$ \\
\hline kakoi mono & かこみもの & mistress \\
\hline kamikashiya & 上菓子や & vendor of expensive sweets \\
\hline kanekashi & 金貸(し), か称かし, 金かし & money-lender \\
\hline
\end{tabular}




\begin{tabular}{|c|c|c|}
\hline kashihonya & かし本や & rental librarian \\
\hline kashoku & 家しよく & house custodian \\
\hline katsuraya & かつらや & wig-maker \\
\hline keikojo & けいこじよ & training hall owner \\
\hline komamonoya & 小まものや & haberdasher \\
\hline komeya & こめや & rice dealer \\
\hline makiya & まきや & picture roll dealer \\
\hline mizu chaya & みづ茶屋 & $\begin{array}{l}\text { owner of a tea house at a temple/ } \\
\text { shrine }\end{array}$ \\
\hline monomorai & 物もらひ; ものもらい & beggar \\
\hline odori no shishō & おどりの師匠 & dance instructor \\
\hline omochiya & おもちや & rice cake-maker \\
\hline (onna)kamiyui & (女)かみゆい,かみゆひ & (women's) hair dresser \\
\hline otaiko; taikomochi & おたいこ;たいこもち & entertainer \\
\hline ryōri(ya) & 料理(や) & restaurant owner \\
\hline sakan & 左官,さくハん & plasterer \\
\hline sakanaya & さかな屋 & fishmonger \\
\hline setomonoya & せと物や & china shop owner \\
\hline shamisenya & さみせんや & shamisen-maker \\
\hline shibai & 芝居, しばみ & theatre owner \\
\hline shichiya & 質屋, しちや, 質や & pawnbroker \\
\hline shichū no urimise & 市中のうり店 & shop owners in the city centre \\
\hline shogaya & 書画や & art and calligraphy dealer \\
\hline
\end{tabular}




\begin{tabular}{|c|c|c|}
\hline shokunin & しよく人 & artisan \\
\hline sono higurashi & その日くらし & day labourer \\
\hline tayu-san & 大夫さん & highest-ranking prostitute \\
\hline tōbutsuya & とうぶつや & imported goods dealer \\
\hline uekiya & う总木や & potted plants dealer \\
\hline unagiya & うなぎや & eel dealer \\
\hline yakusha & やくしや & actor \\
\hline yaneya & やねや & thatcher \\
\hline yaoya & 八百や & vegetable dealer \\
\hline yashiki akindo & やしき商人 & real estate dealer \\
\hline$y \bar{o} k y \bar{u} b a$ & 楊弓場 & archery-range owner \\
\hline yomise akindo & よみせあきんど & booth sellers at festivals \\
\hline yose & よせ & cabaret artists \\
\hline yuya & ゆや & bathhouse owner \\
\hline zatō & 座とふ & theatre group leader \\
\hline
\end{tabular}

Table 2 Economic winners mentioned in awate-e

\begin{tabular}{|l|l|l|}
\hline \multicolumn{3}{|c|}{ Economic winners mentioned in awate-e } \\
\hline transcription & Japanese & translation \\
\hline aramonoya & あらものや & household goods dealer \\
\hline bagushi & ばぐし & saddler \\
\hline basue (no) ienushi & 場末家主 & house owner in the suburbs \\
\hline chasen no sendo & 茶船の船頭 & boatman of a swimming shop \\
\hline
\end{tabular}




\begin{tabular}{|c|c|c|}
\hline chōchinya & てうちん屋 & lantern-maker \\
\hline dōchū ukeoi & 道中うけおい & travelling prostitute \\
\hline funenori & ふねのり & sailor \\
\hline guinomi izaka & ぐいのみ居酒 & stand-up sake bar \\
\hline gusokushi & 具足師，ぐそくし & weapon smith \\
\hline hatagoya & はたごや & inn owner \\
\hline hikyaku & 飛脚 & courier \\
\hline hitoiri ninsoku yado & 人入にんそくやど & cheap inn \\
\hline hiyō(tori) & ひよう(とり) & day labourer \\
\hline hyakushō & 百姓 & farmer \\
\hline issen meshi & 一せんめし & cheap inn \\
\hline jinushi & 地主 & landowner \\
\hline jorōya & じやろうや & brothel \\
\hline kagoya & かごや & sedan-bearer \\
\hline kanbutsuya & かんふつや & grocer \\
\hline kappaya & かつぱ屋 & raincoat-maker \\
\hline karuko & 軽子，かるこ & luggage-arrier \\
\hline katanakaji, katanaya & 刀かぢ, かたなや & swordsmith \\
\hline kumosuke & くもすけ, <も助 & carrier \\
\hline machizukai & まちづかい & errand boy \\
\hline mago & まご & packhorse leader \\
\hline meshimori & 飯盛, めしもり & inn prostitute \\
\hline
\end{tabular}




\begin{tabular}{|l|l|l|}
\hline nagamochi & ながもち & clothing basket-maker \\
\hline ninsoku & 人足, にんそく & day labourer \\
\hline norimono(ya) & 乗物 (や) & sedan hirer \\
\hline sakagomo & さかごも & $\begin{array}{l}\text { maker of straw jackets for sake } \\
\text { bottles }\end{array}$ \\
\hline sendo & 船頭, 船どう & boatman \\
\hline shariki & 車力, しやりき, 車りき & carter \\
\hline shiomonoya & しほものや & corned fish dealer \\
\hline temawari rokushaku & 手廻り六尺 & sedan-bearer of rich people \\
\hline teppōkaji & 鉄砲鍛冶, てつほうかじ & gunsmith \\
\hline togishi, togiya & とぎし, とぎや & grinder \\
\hline tsukamakishi & つかまきし & sword hilt binder \\
\hline tsuzuraya & つづらや, つ〉ら屋 & clothing basket-maker \\
\hline umakata & horse leader \\
\hline
\end{tabular}

Apart from trades, other personified concepts are frequently found in awate-e. The rich man is one such, representing all wealthy people who had to spend a lot to move their households into the country. He can be recognised by gold coins on his clothes and by his costly clothing. He also wears an unhappy facial expression (for an exception, see Kanemochi no daikoku, The Rich Taikoku). The rich man is identified by the following names: mochimaru 持丸 (money owner; sometimes 持。 using a circle, which is also pronounced 'maru'), marumochi 丸持 (money owner), kanemochi 金持 (money owner), monomochi ものもち (owner of things), or fuku$s h a$ 福者 (lucky person).

An important feature which distinguishes awate-e from Boshin-sensō-e is the subject of the Westerner, often accompanied by the characters for gai(koku)jin 外( 国)人, ijin 異人 (stranger), or also töjin 唐人 (or とう人, foreigner). In one print, instead of these rather neutral words, the word warumono わるもの ('bad person') is used. The Westerner has two manifestations in awate-e: as a Westerner with a beard and Western attire and as a visible or invisible threat, for example, in the 
shape of a giant hand. The Westerner symbolises either all Western foreigners as the target of xenophobia, or the British and the British warships in the Bay of Edo.

A personification of an inanimate object important in many awate-e is the concept of inaka 田舎. The word means 'countryside' as opposed to the city. In several awate-e, inaka is depicted as a person and sometimes even speaks. The reason for the personification is that not only representatives of specific trades living in the countryside, but the countryside in general profited from the influx of money and people, strengthening it at the expense of the cities of Yokohama and Edo.

\section{Characteristic scenes in awate-e}

Ordering the events shown in awate-e chronologically, the first is of course the flight from Edo. Though we know today that Edo was not actually attacked by the British ships, the danger was real at the time. Even though the topic of the flight gave the genre its name, only three of the 21 awate-e analysed belong to this category.

An even more typical scene is the depiction of a rich man contemplating his choices or lamenting the loss of his wealth. The rich man is always the central person in these prints, shown sitting and with an unhappy, pondering face (the only exception is Kanemochi no daikoku). Six of the awate-e analysed in this paper show an unhappy rich man.

The third typical scene shows two opposed or fighting groups, consisting of members of profiting and losing trades (see Tables 1 and 2). In one awate-e they have sad or happy faces respectively, but are not in open opposition. In four awate-e the trades are attacking or defending a Westerner, depending on each trade's economic situation at the time.

The fourth typical scene shows a Westerner together with Japanese people, who react to his presence in different ways. The people in Edo viewed the arrival of the Westerners as the root of their misfortune, as can be seen in many ukiyo-e that show Westerners being attacked (Minami 1999: 67). Among awate-e are several prints where one Westerner is being attacked by the losing side. The winning trades are always there, holding back the attackers. The Westerner is shown as crying and weak, lying on the ground. In two prints, Westerners and Japanese are competitors, and in three awate-e, Westerners are idle bystanders.

The prints in the original study are loosely grouped by these topics, as several prints fit into more than one topic. Restrictions on space mean that in this paper only one of each topic is translated and interpreted in more detail. 


\section{Textual and picture analysis of four representative awate-e}

In the following part of this paper, one representative awate-e for each of the abovementioned categories will be translated and discussed: the flight from the endangered areas, the troubled rich man, two opposing groups (profiting vs. losing trades), and the Westerner being attacked. ${ }^{2}$

Dokyō no hara no ue - Awate to iu te

Figure 2 Dokyō no hara no ue - Awate to iu te

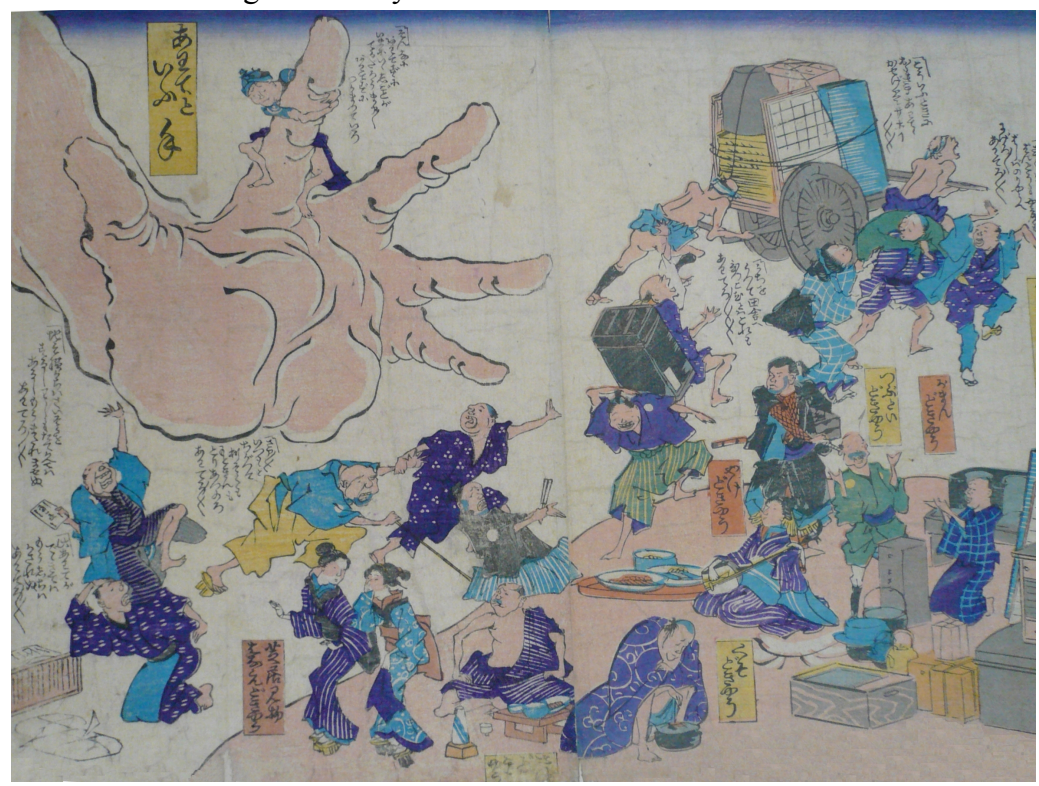

Source: Machida City Museum

The print Dokyo no hara no ue - Awate to iu te is a diptych where each of the sheets has its own title. The right half is Dokyō no hara no ue どきやうのはらの上 (On the Plain of Courage), and the left part is called Awate to iu te あわてといふ手 (The Hand called Hysteria).

It shows people fleeing from a giant hand. A man is clinging to the hand's index finger and shouting to those below him. The people under the hand are fleeing in panic, but at the right side of the print the carriers and carters seem happy. As in another awate-e (Shinsaku ukiyo dōchū 新作浮世道中, New Picture: Journey through the Floating World; see, e.g., Nowak 2010), there is a 'Plain of Courage',

2 For further information on, as well as translations of all the 21 awate-e prints I was able to find during my research, please refer to the WDB (database number in brackets) and my MA thesis (Nowak 2010). 
where men are celebrating, a geisha is playing the shamisen and nobody is paying attention to the giant hand. Some characters have writing without a frame next to their body, which is what the person is saying. These 'speech bubbles' can be recognised by the characteristic hook shape at their beginning.

A translation of the textual part of this awate-e is given next, followed by a short commentary.

Figure 3 Dokyō no hara no ue - Awate to iu te (altered)

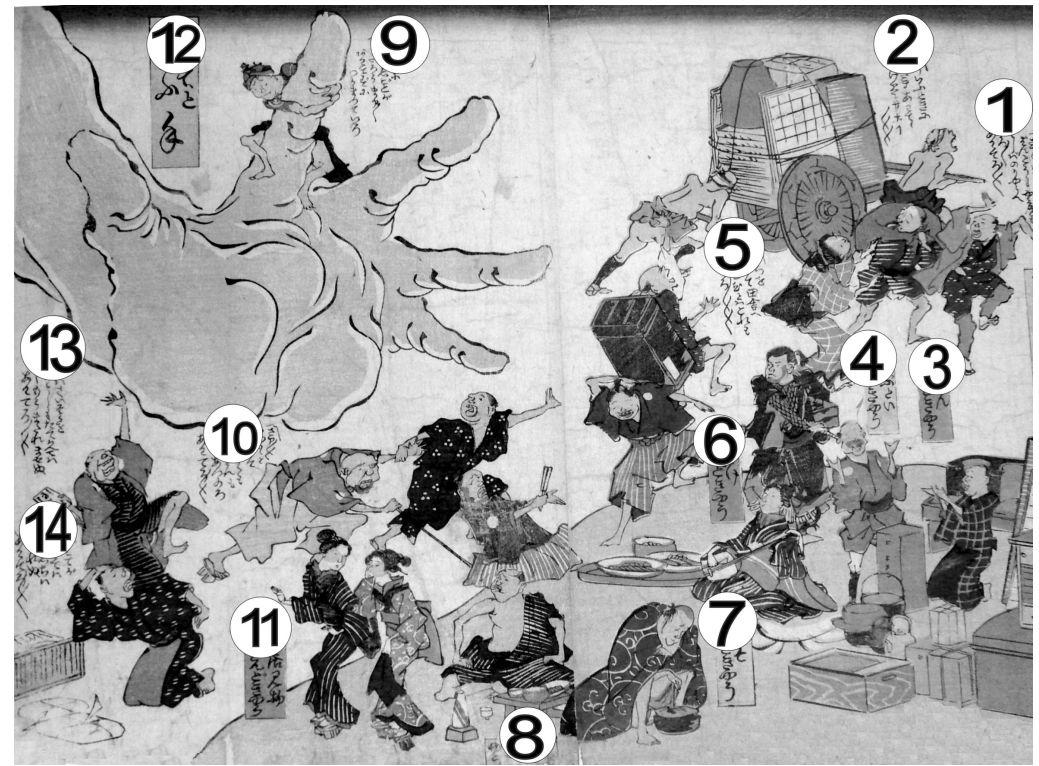

Source: Machida City Museum

1. Saa saa ima no uchi / bantō mo nyōbo mo / hashiba no ryō e / nigero nigero / awatero awatero awatero. さアさアいまのうち ばんとうも女房も ばしバの りやうへ にげろにげろあわてろあわてろあわてろ 'Go, go, store manager and wife, flee to your secondary residence near the mooring, as long as you can! Flee! Hurry, hurry, hurry!'

2. Kō iu toki ni / otosama awatete / kasege tsukushimasu, hoi hoi hoi hoi. こういふとき におとさまあわてて かせげ尽升ホイホイホイホイ'At times like these, the father hurries to earn as much as possible! Heave-ho, heave-ho, heave-ho, heave-ho!'

3. Gaman dokyōがまんどきやう 'Tolerant courage'

4. Zubutoi dokyōつぶといどきやう 'Impudent courage'

5. Uchi o / utte inaka e / hikkomu koto wa dore mo / awatero awatero awatero awatero. うちをうつて田舎へ ひつこむこと八どれも あわてろあわてろあわてろあ わてろ 'All are hysterical and sell their houses and retreat into the country.' 
6. Yake dokyō やけどきやう 'Desperate courage'

7. Kuso dokyōくそどきやう 'Foolhardy courage'

8. Sake dokyōさけどきやう 'Drunk courage’

9. Sonna ni / awatezu ni / ima ni ii shigoto ga / deru darō maa maa / awatezu ni / tsukamatte iro. そんなに あわてずに いまにいいしごとが でるだろうまアま アあわてずに つかまつていろ 'Don't be so hysterical! You will soon have good work, so don't be so hysterical and let yourselves be caught!'

10. Sā sā sā / itsumo to / chigatte / risoku mo / motokin mo / toriatsumero / awatero awatero awatero さアさアさア いつもと ちがつて りそくももときんも とりあつめろ あわてろあわてろあわてろ 'Well, well, well, other than usual collect the interest too and the invested capital! Hurry, hurry, hurry!'

11. Shibai kenbutsu / hana san dokyō しばい見物 はなさんじきやう 'The courage of a geisha visiting the theatre.'

12. Awate to iu te あわてといふ手 “The Hand called Hysteria.'

13. Jinushi sama wa saisoku o / suru shi watakushi mo tatekaete wa / aru shi mō mataremasenu. / awatero awatero awatero. 地主様はさいそくを するしわたく しもたてかへて八 あるしもうまたれまセぬ あわてろあわてろあわてろ 'The land owner is urging me already and I have debtors as well, so I can't wait any longer! Hurry, hurry, hurry!'

14. Kono awate ga / dete kite wa / mō shichi wa / kasarenu / awatero awatero awatero. 此あわてが でてきて八 もうしち八 かされぬ あわてろあわてろあわて ろ 'Since this hysteria has started, I am receiving no objects to pawn anymore! Hurry, hurry, hurry!'

From the text alone it is apparent that this print is an awate-e. It can be considered a textbook example for the genre. In no other awate-e does the word awate appear this often, and the print describes the whole situation at once, the exodus from the endangered Bay of Edo as well as its effects. A carter speaks of seizing the opportunity by earning as much as he can, as opposed to a geisha, who is being called courageous for visiting the theatre (because she stayed in the endangered area and also because she spent money on entertainment.) Westerners are not directly mentioned in this awate-e, though they are unmistakably represented by the giant hand. 
Zen'aku shian saichū

Figure 4 Zen'aku shian saichū

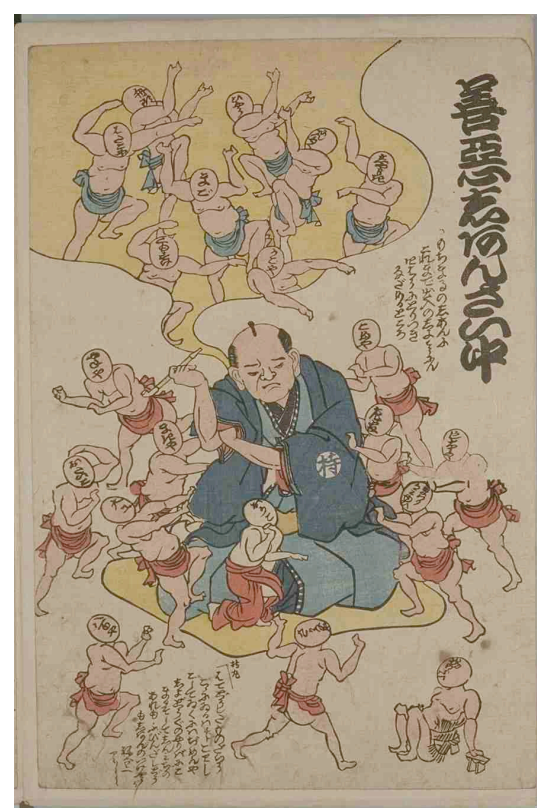

Source: Historiographical Institute, University of Tōkyō

The title of the print, Zen'aku shian saichū 善悪しあんさい中, can also be pronounced Yoshiashi shian saich $\bar{u}$ and means 'Contemplating Good and Bad'. The centre of the scene is a rich man, sitting on a golden cushion with a sad and pensive look and smoking. Above his head there is a thought bubble containing manikins in blue loincloths and with writing instead of faces. Another group of manikins is gathered around the cushion, all wearing red loincloths, except for the beggar (monomorai 物もらい) in the lower right corner, who seems to be wearing a straw loincloth.

These loincloth-clad little men are part of a long tradition of drawing manikins with text instead of faces. The first example was probably a kibyōshi 黄表紙 (booklet with illustrated stories) from the 18th century (see Brandl 2009: 44). Utagawa Kuniyoshi 歌川 国芳 used this theme of zendama 善玉 ('good heads') and akudama 悪玉 ('bad heads'), for instance, in his nishiki-e Suikoden. Urashima Tarō in 1844 (Brandl 2009: 46; WDB 2006 \#Suikoden. Urashima Tarō). Originally, the loincloth manikins had either 'good' (zen 善) or 'bad' ( $a k u$ 悪) instead of faces. 
The text alongside the title is:

Mochimaru no shian ni / kore made deiri no shiyōnin / kihō ni toritsuki / nadameru tokoro. もちまるのしあんに これまで出入のしようにんきはうにとりつき なだめる ところ 'In the bubble of thoughts of the rich man are the workers who come and go, bewitching and placating him.'

Mochimaru: Sate dō shita mono darō, koko ni iru wa chitto kowashi, koshite iku ni wa jimen ya, shodōgu no yariba ni komaru, soshite shinmichi no are mo fubin da shi, dō mo shian no tsukeyō ga nee wae aaa. 持丸「さてどうしたものだらうここにみるハじつ とこわしこしてみくにハお゙めんやしよどうぐのやりバにこまるそしてしんミ ちの あれもふびんだしどうもしあんのつけやうが ねへわへ アアア Rich man: 'Well, how is this? I am a little afraid to stay. If I move, I have the problem with the luggage and the land and a storage area for everything. And the thing with the new road is inconvenient. However much I think about it, I arrive at no conclusion!'

The new road the rich man is referring to is probably the one that was created as an alternative to the Tōkaidō right after the Namamugi incident. The new road was forbidden to foreigners, to prevent further clashes (see Black 1968: 142-144).

The text comprising the faces of the manikins within the thought bubble read as follows (from left to right):

Shariki しやりき (carter), ninsoku にんそく (labourer), kago-ya かごや (sedan-bearer), hiyōひよう (day labourer), mago まご (pack horse leader), kumosukeくもすけ (carrier), sendō 船頭 (boatman), hatago-ya はたこや (inn).

The rich man is surrounded by the following manikin trade representatives (from left to right):

Kashihon-ya かし本や (rental library), kome-ya こめや (rice dealer), sakan 左官 (plasterer), mawari kamiyui (hairdresser in the neighbourhood), sakana-ya さかな屋 (fishmonger), furoko ふろこ (bathhouse girl), makiya まきや (picture roll dealer), daiku 大工 (carpenter), yane-ya やねや (thatcher), otaiko おたいこ (entertainer), yaoya 八百や (vegetable dealer).

The print shows the fate of the rich city dweller, who has to spend a lot of money to move into the country. The manikins in red try to calm the rich man. These are the trades out of luck, who want the rich man to stay in Edo with them. The blue manikins in the rich man's thoughts are trying to throw him into panic. These are the trades earning heaps of money thanks to the many people leaving the endangered areas. In between sits the rich man, pondering whether to leave, which would be expensive (and benefit the blue manikins) or to stay (which would benefit the red manikins). 
Taihei yūbi ron

Figure 5 Taihei yūbi ron

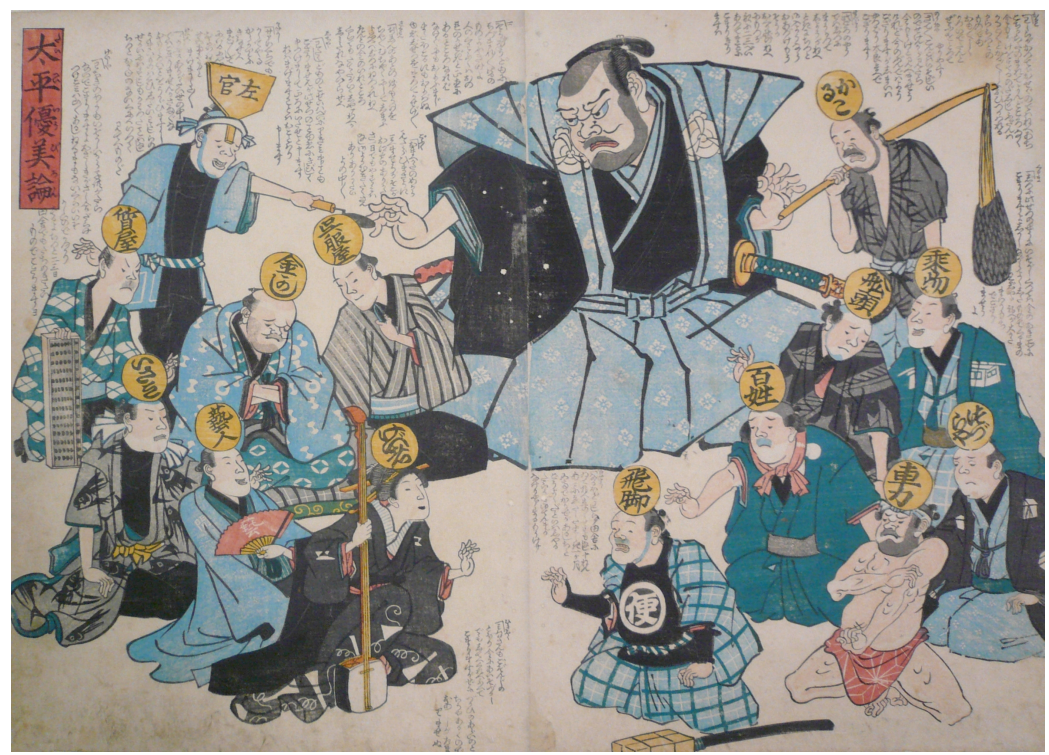

Source: Machida City Museum

The title Taihei yūbi ron 太平優美論 (Discussion on Peace and Elegance) is written on the left sheet of this diptych in a red box.

This is a typical print showing two groups of people sitting opposite to each other. The left group contains geisha げい者, entertainer (geinin 藝人), draper (gofukuya 呉服屋), money-lender (kanekashi 金かし), pawnbroker (shichiya 質屋), plasterer (sakan 左官), and fish dealer (the fish isaki いさき, chicken grunt, represents the trade here). The right group consists of carrier (karuko かるこ), sedanlender (norimono 乗物), boatman (sendō 船頭), clothing basket-maker (tsuzura-ya つづらや), carter (shariki 車力), farmer (hyakushō 百姓), and courier (hikyaku 飛 脚). On both sides appear happy and unhappy faces, even though the economic winners are to the right and the losers to the left. A samurai is standing between them, much larger than the others and frozen in an actor's pose and facial expression.

The text in this print consists of many "speech bubbles", each marked at the beginning by an abbreviation or the full name of the trade that is speaking. Part of the Japanese text of this print can be found in Minami (1999). For these parts, only the transcription and the English translation are included here.

Karuko: Washira ga katte de kasegu no de wa nē, achi kochi kara tanomarete, yondokoro naku, kane mōke o suru no da. Shikashi fudan wa karuko karuko to karugarushiku oitsu- 
kawareru kara, chii to no mono de mo omoku shite katsuide, tanto zeni o totte yariyasu (Japanese see Minami 1999: 64). Carrier: 'It is not as if we are earning out of selfishness! We are getting job offers from all sides, so we have no choice but to earn money. But because we are normally treated like slaves and carelessly called "Carrier! Carrier!", we act as if even a very light item was very heavy and demand a lot of money from them.'

Kuruma: Jitsu ni kono setsu no yō ni isogashikutte wa kane no oku tokoro ni komarimasu yo. Shikashi nagara yoku shita mono de kuruma no wa jā nē ga ōkata mawarimochi de gozarimasshō yo (Japanese see Minami 1999: 64). Carter: 'As unbelievably busy as I am at the moment, I don't know what to do with the money anymore! But since I did a good job and am no cartwheel, let us be generous and take turns!'

Norimonoya: Sate sate kondo wa isogashii / no de seken kara mitara / kane mōke to miemashō / keredo ima no bun de wa yō / gozarimasu ga shimai wa yappari tarai de / gozarimasu. のり物や「さてさてこんど八いそがしいのでせけんから見たら 金もうけと見へませう けれど今のぶんで八よう ござりますがしまい八やつぱ り太良意で ござります Sedan-lender: 'Well, well, because I am very busy this time, it may look as if I am earning money to others. At the moment it is still alright, but in the end it will be tubs (in which the customers will be carried, because the demand will be so high that there will be no sedans available).'

Sendō: Konogoro no yō de wa jitsu ni mōkatte shimau ga nē (Japanese see Minami 1999: 64). Toki ni chitto go-iriyō nara / oazuke mō /sō ka / okuri jō no nē / nimotsu ga fune ni ni, san bei / atte makoto ni / komarikiri / masu wa. せんどう「ときにちつとご入ような らおあづけもう そうか おくり状のねへ にもつが船に二三べい あつてま ことにこまりきり ますハ Boatman: 'In times like this you really earn whether you want to or not. If you need some money, do you want me to lend you some? Two, three boats full of luggage without freight documents really create great difficulties for me!'

Hyakushō: Naruhodo washirā inaka ni ite hoka e tachinoku sewa mo nashi, jūnen ato ni tatashita zashiki o ikkagetsu goryō de karide ga aru shi, chito gōyoku da to iwasharu darō ga (Japanese see Minami 1999: 64). O-tenma ga / nakerya maru mōke sa 御てんまが な けりやアまるもうけサ Farmer: 'I understand! Probably because we live in the country and do not have to move somewhere else and there are tenants, who pay five ryo per month for a ten-year-old guest room, we are called a little greedy. But if it were not for these demons, it would be a clean profit!'

Hikyaku: Mina san mo gozonji no / tōri kane ni aiso zukashi / de mo shitē kurē fuete / komarimasu (Japanese see Minami 1999: 64). Ga zeni zukai no arai no to / chūya aruku no de / o-ashi ga tamarimasenu. がぜにづかひのあらいのと ちうやあるくので おあ しがたまりませぬ Courier: 'As you all know, I have problems because my money increases so fast, that I am nearly sick of it already. But spending day and night with the spendthrifts - that my legs cannot endure.'

Kō: Sono hō domo ni / chizumare chizumare ano / mono yō kike yo / Hito no kafuku wa ono / re no kasegi to shōjiki ni / aru tokoro nareba / nageku ni mo oyobu maji / Mata okoru ni mo oyobane / yue jisetsu o matte kasege kasege. 工「「そのほうどもに ちづまれ ちづまれあの ものよふきけよ 人のくおふく八おの れのかせぎと正直に あ るところなれば なげくにもおよぶまじ またほこるにもおよばね ゆ总じせつ 
をまつてかせげかせげ Carpenter: 'You over there, be silent, be silent! Listen well. Since the fate of the people lies in your profit and honesty, we don't want to complain and we won't get angry, so wait for better times and earn, earn!'

Gofuku: Omae-kata no me kara / mitara hima sō ni / mimashō ga soko ga / o-Edo no arigata / sa ichinichi de mo yasumi wa / nashi Go-yōmuki takusan / ari arigatai / yo no naka yo no naka. ごふく「おまへかたのめから みたらひまさうに 見ませうがそこ が お江戸のありがた さ一日でもやすミハ なし御ようむきたくさん ありあ りがたい よの中よの中 Draper: 'For your eyes we may seem idle, but here you see the worth of Edo. I have not one free day. There is a lot of business. They're times, times to be thankful for.'

Sakan: Jishin no ato no zeni mōke o, cha cha muchaku ni shite shimau to omoeba, jitsu ni ne tsurarenē, tanto no kane no iredokoro, kura demo tateta ga ii ja nē ka, shimitare na yatsura (da) zē (Japanese see Minami 1999: 65). Plasterer: 'If I think how effortlessly I earn after an earthquake, I really do not get tempted. I built a storage shed for the heaps of money to be sure, but may I not? You are scrooges!'

Shichiya: Watakushi domo no tosei wa betsu ni riki mimasu koto mo / gozarimasen ga kono setsu no koto yue ni kibishiku / mōshi tsukemashite kokoro ni itase to mōshimasu / reba magemasu koto wa okotowari mōshimasu. しちや「わたくしどものとせいハベつ にりきミますことも ござりませんが此せつのことゆえにきびしく申つけまして 心ろにいたせと申ますれバまげますこと八おことわり申ます Pawnbroker: 'Our livelihood is never very comfortable, but because of the current events I implore you, do your best, because we will not yield!'

Kanekashi: Sā ikura de mo / kashite yaru / kara kari ni / kinasē / mago mago shite / nigeru nyā / oyobanē / nijūgo ryō ichi bu to / makemashita makemashita (Japanese see Minami 1999: 65). Money-lender: 'I will lend you any amount, so come and borrow money! I only have 25 ryō and one bu left, which is not enough to flee confusedly. I paid extra!'

Geinin: Sō desu, arigatai yo no naka / de wa gozaimasen ka. Samazama na / omoshiroi koto o ukagaimasu shi / umai mono wa kui shidai watashira no sekai ni wa sukoshi mo kawatta koto wa nashi. / Chitto okane no nai kuni e itte / mitē mono da. げい人「「ウ デスありがたい世の中 でハござりませんかさまざまな おもしろいことをうか がひますし うまいものハくひしだいわたしらのせかいに八すこしもかわつたこ と八なし ちつとおかねのないくにへいつて見てへものだ Entertainer: 'Isn't this a time to be thankful for? One hears many different interesting things. After one has eaten something good, the world hasn't changed a bit. I feel like travelling into a country where money doesn 't exist.'

Geisha: Wachiki no hō mo isogashii kara kodomo ga tara / naide komarimasu yo. Ozashiki ga sashiai darake / tsukekomi wa yamayama aru shi neru ma mo nai kurai isogashii no de [illegible] suru yo chitto ni san nichi inaka de mo tachinokitai / mono de gozarimasu yo. げいしや「わちきもほうもいそかしいから子供がたら ないでこまりますよ お ざしきがさし会だらけ つけこミ八山々あるしねるまもないくらいいそかしいの でするよちつと二三日田舎でもたちのきたい ものでこざりますヨ Geisha: 'Because I am very busy as well and the children are not enough, I am in trouble. I am so 
busy, that my appointments constantly overlap and I have little time to sleep. I would very much like to move into the country for two or three days.'

In this print, many trades get to speak about their situation. There is much mention of highly increased demand for transporting trades as well as for rooms in the country. The trades profiting try to defend themselves by claiming facetious repercussions obviously to be construed negatively for earning too much money and reminding the others that it is not their fault that they are making profits and the others are not. On the not so profitable side, there are more subtle hints that these trades are having hard times. The money-lender does not have enough money to flee into the country and the entertainer would like to go to a place where money does not exist. It is interesting that the draper and the geisha claim to be busy. This is probably irony or intentionally misleading, since the draper confirms in the same sentence that he seems idle, and the geisha wants to go to the country (presumably for safety and better business) and has few apprentices, because many children have moved with their parents and others were sent away from the coast for protection. There are also obvious references to foreigners (called 'demons'), who are faulted for the bad (or good, but unfair to the not-so-happy countrymen) situation.

\section{Tōji seisui kurabe}

Figure 6 Tōji seisui kurabe

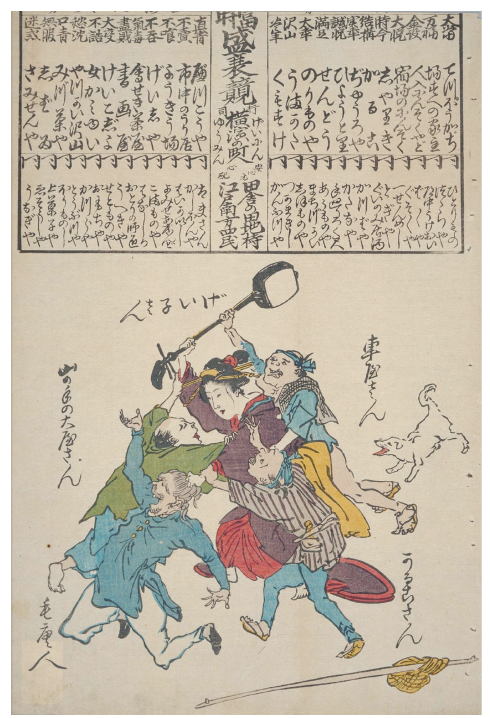

Source: Waseda University Library 
Tōji seisui kurabe 当時盛衰競 (Comparison of Current Fates) is comparatively simple in design and shows a classic awate-e subject, a Westerner being attacked.

In the picture, a geisha is holding a Western foreigner by his hair while trying to hit him with a shamisen (which probably never happened in reality), a composition that hints at the situation without being too obvious and gives the print an amusing tone. The geisha here of course represents her own and other trades, which suffered a sharp decline in business because of the British ships threatening to attack.

She is hindered by a carter, a carrier and a house owner from the Yamanote 山の 手 area, representing the profiting trades, who are thus shown protecting the Westerner. Yamanote was the area north and west of the castle, stretching into the hinterland of Edo and was the rural counterpart to the urban Shitamachi 下町 (Schwan 2003: 36). Suddenly everybody wanted to live here.

Cut off in the WUL version is the topmost row, containing headers for the columns. Fortunately, Minami shows another print of the same awate-e, which is owned by the Tobacco and Salt Museum and more damaged, but the headers are there. The characters on the right read ryūko no hō 流行の方 ('popular side'), and on the left there is written oaida no hō おあいだの方 ('unemployed side'; see Minami 1999: 73). Below ryūkō no hō we find the following text:

Ōatari teppōkaji, manpuku basue no ienushi, kaneyaku hitoiri ninsoku yado, ōetsu shukuba no ninsoku, jikon shariki, kekkō karuko, jikkō jorōya, seietsu hiyōtori, manzoku sendō, daikō norimono-ya, takusan umakata, hōnen kumosuke; dō hitorimono, tsuzura-ya, dōchū ukeoi, basha, gusoku-ya, issen meshi, togi-ya, guinomi izaka, kappa-ya, katana-ya, temawari rokushaku, aramono-ya, machizukai, shiomono-ya, tsukamakishi, kanbutsu-ya 大 留てつぽうかぢ 万福 場すへの家主 金役人入にんそくやど 大悦 宿場の にんそく 時今 しやりき 結構 かるこ 実幸 じやろうや 誠悦 ひようとり 満足 せんどう 大幸 のりものや 沢山うまかた 豊年 くもすけ 同 ひと りものつつらや道中うけおい ばしやぐそくや-せせんめしとぎやぐ いのみ居酒 かつぱや かたなや 手廻り六尺 あらものや まちづかいしほ ものや つかまきし かんふつや

'Bullseye: gunsmiths; all good luck of the world: house owners in the suburbs; money: labourer inns; great joy: labourers at travel stations; from now on: carters; very good: carriers; true luck: brothels; pure delight: day labourers; content: boat men; good luck: sedanlenders; plenty: horse leaders; good year: carriers; also: bachelors, clothing basket makers, labourers on travel routes, horse carriages, armourers, 1-sen-food, grinders, cheap bars, rain coat-makers, swordsmiths, seda-bearers, rich men, household goods dealers, errand boys, salted fish dealers, sword hilt makers, grocers';

Below oaida no hō is the text:

Massao bekkō-ya, fubai shichū no urimise, fushoku yōkyūba, fudon geisha, kidoku kaiseki jaya, jinzai shogaya, taihen keikojo, futsume onnakamiyui, shūjin yakkai takusan, kuchiao mizu jaya, mufuku shibai, meiwaku s(h)amisenya; dō tayū-san, kashihonya, haikaishi, 
yomise akindo, komamonoya, hanashika, odori no shishō, uekiya, setomono-ya, omochiya, katsuraya, tōbutsuya, horimonoshi, kamikashiya, esōshiya, unagi-ya

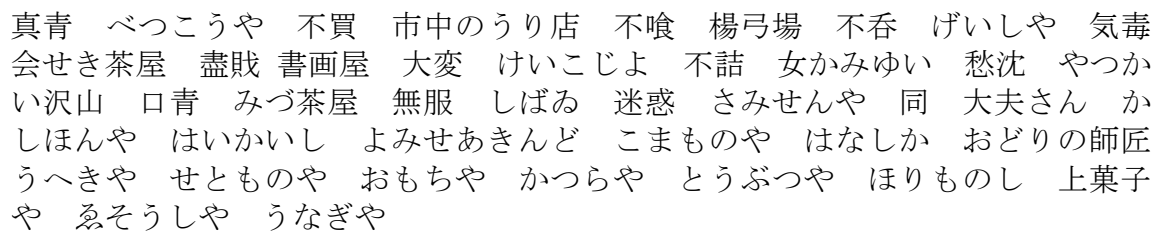

'white-faced: tortoiseshell carvers; no customers: shops in the city centre; no food: archery galleries; nothing to drink: geishas; pitiful: tea houses for celebrations; no thieves anymore: painting and calligraphy dealers; terrible: practice halls; checkmate: lady's hairdressers; depression: inconvenient things; pale: tea houses at shrines or temples; no clothes: theatres; annoyance: shamisen sellers; also: highest-ranking prostitutes, rental libraries, haikai poets, stalls at festivals, haberdashers, storytellers, dance instructors, potted plants sellers, porcelain shops, rice cake-makers, wigmakers, imported goods dealers, wood carvers, premium sweets dealers, picture book dealers, eel dealers';

The textual part of this awate-e lists profiting and losing groups of people in the tabular form of a sumō ranking, though no sumō terms appear. In their stead are words describing the situation of the groups mentioned. Most trades have already appeared in other awate-e. Interesting in this awate-e is the bachelor on the winning side, earning his place by not having a family to move into the countryside. Worth pointing out on the losing side is the "white-faced" bekkoya, a trade that appears only in this awate-e. A bekkoyya carved hair ornaments like pins and combs from tortoise shell, solely decorative products, which were generally not in high demand at the time. Additionally, the main clients of the bekkoya were women in the entertainment business, who suffered from a loss of business themselves and therefore probably reduced or stopped spending money on ornaments.

\section{Conclusion}

Why is the geisha hitting the Westerner? The reason why the subject of a geisha attacking a Westerner appears in four of the 21 prints will have become clear by now: the geisha is an important representative of the trades losing business due to the British threat. Showing her physically venting her anger on the source of the trouble, the Westerners, is an amusing way to satirise the situation and probably also represents the feelings of the creators and many consumers of the awate-e.

As the analysed prints clearly show, the tense situation after the Namamugi incident led to a divide: profiting vs. losing trades, and people moving into the countryside for safety vs. people staying and ridiculing those leaving. This last group seems to have included the awate-e creators themselves, which seems logical considering 
the connection of the ukiyo-e business with the entertainment business and the nonvital, entertaining nature of the prints. So the awate-e creators can be considered part of the losing side. The translation and interpretation of the awate-e have revealed an unmistakable bias: there is a hostile mood against people moving into the country (frequently called 'cowards') and of course against Westerners. The trades suddenly profiting are sometimes called greedy and self-serving. People remaining in the endangered areas are called courageous and there is a clear bias towards the trades out of luck and the anti-foreigner words of the Tennō. In this, the creators of the awate-e of course represented their own views, but surely also a significant part of popular opinion, at least in the endangered areas. Because of this bias and since these prints were sold in the city, many of the buyers of awate-e were probably part of the not-so-fortunate trades and among those staying in the endangered areas (due to a lack of money, no place to go, or taking a chance; the reasons were probably manifold).

As has, I hope, become apparent through this analysis, awate-e are an interesting source of quite detailed information on an event left out in most history books (maybe because of its harmless conclusion). Of course, translations as well as picture analyses leave considerable room for interpretation, so the results may not be 100 percent accurate. But for answering the questions posed in this paper the analysis of the four awate-e selected has proved sufficient and has supplied detailed information that cannot be found in history books. 


\section{REFERENCES}

Black, John Reddie. Young Japan: Yokohama and Yedo 1858-79, Volume 1. Tokyo: Oxford University Press, 1968. [Oxford in Asia Historical Reprints]

Brandl, Noriko Deushi. "Die nishiki'e-Karikaturen von Kuniyoshi.” Ph.D. thesis, University of Vienna, 2009

Genshoku ukiyo-e daihyakka jiten henshū iinkai 原色浮世絵大百科事典編集委員会 [Editorial Committee of the Great Encyclopedia of Woodblock Prints in Colour]. Genshoku ukiyo-e daihyakka jiten 原色浮世絵大百科事典 [Great Encyclopedia of Woodblock Prints in Colour]. Tōkyō: Taishūkan shoten, 1980

Groemer, Gerald. "Singing the News: Yomiuri in Japan during the Edo and Meiji Periods." In Harvard Journal of Asiatic Studies, 54/1, 1994, pp. 233-261

Hashimoto Mitsuru 橋本満. “Collision at Namamugi.” In Representations, 18, 1987, pp. 69-90

HIUT (Historiographical Institute, University of Tōkyō). "Tōkyō Daigaku Shiryō Hensanjo Nishiki-e Korekushon” 東京大学史料編纂所錦絵コレクション [Nishiki-e Collection of the Historiographical Institute, University of Tōkyō]. Historiographical Institute, University of Tōkyō website, http://www.hi.u-tokyo.ac.jp/personal/yokoyama/nishikie/cover.html, accessed September 2011

International Ukiyo-e Society. Ukiyo-e Daijiten 浮世絵大辞典. [Great Encyclopedia of Woodblock Prints]. Tōkyō: Tōkyōdō, 2008

Katō Mitsuo 加藤光男. “Ukiyo nishiki’e o yominaosu” 浮世錦絵を読み直す [Rereading Coloured Woodblock Prints]. In Genten de tanoshimu Edo no sekai 原点で楽しむ江戸の世界 [Enjoying the World of Edo from its Starting Point], edited by Asano Akira 浅野晃 and Katō Mitsuo 加藤光男. Tōkyō: Ribun shuppan, 2004, pp. 66-145

Konishi Shiro 小西四郎. Nishiki-e. Bakumatsu Meiji no rekishi 2: Yokohama Raikō 錦絵 幕末明 治の歴史2横浜来航 [Coloured Woodblock Prints: The History of Meiji 2: Ships Arrive at Yokohama]. Tōkyō: Kōdansha, 1977

Linhart, Sepp. “Die Welt - ein Ken-Spiel.” In Japan - Reich der Spiele, edited by Stanca ScholzCionca. Munich: Iudicium, 1998, pp. 193-234

Linhart, Sepp. "Japan.” In Ostasien 1600-1900. Geschichte und Gesellschaft, edited by Sepp Linhart et al. Vienna: Promedia, 2004, pp. 40-54

Linhart, Sepp. "Kawaraban - Enjoying the News when News was Forbidden." In Written Texts Visual Texts: Woodblock Printed Media in Early Modern Japan, edited by Susanne Formanek and Sepp Linhart. Amsterdam: Hotei Publishing, 2005a, pp. 231-250

Linhart, Sepp. "Shinbun nishiki-e, Nishiki-e shinbun: News and New Sensation in Old Garb at the Beginning of a New Era." In Written Texts - Visual Texts: Woodblock Printed Media in Early Modern Japan, edited by Susanne Formanek and Sepp Linhart. Amsterdam: Hotei Publishing, 2005b, pp. 341-356

Matsumoto Kenichi 松本健一. Nihon no kindai 1. Kaikoku-ishin. 1853-1871 日本の近代 1 開 国・維新-1853-1871 [Japan’s Modern Period 1: Opening of the Country - Restoration, 1853-1871]. Tōkyō: Chūō Kōronsha, 1998

Minami Kazuo 南和男. Bakumatsu ishin no fūshiga 幕末維新の諷刺画 [Caricatures of the Time of Bakumatsu and the Restoration]. Tōkyō: Yoshikawa Kōbunkan, 1999

Nagura Tetsuzō 奈倉 哲三. Etoki bakumatsu fūshiga to tennōo 絵解き 幕末諷刺画と天皇 [Explained Through Pictures: Caricatures of the Bakumatsu Era and the Emperor]. Tōkyō: Kashiwa Shōbo, 2007

Newland, Amy Reigle. The Hōtei Encyclopedia of Japanese Woodblock Prints. Leiden: Hōtei Publishing, 2005 
Nihon Kindaishi Kenkyūkai 日本近代史研究会 [Japanese Modern History Research Society]. Gahō kindai hyakunenshi 1.1850-1872 画報近代百年史1・1850-1872 [Illustrated History of the Century of Modernity 1: 1850-1872]. Tōkyō: Nihon Tosho Sentā, 1989

Nowak, Hannah. "Warum schlägt die Geisha den Ausländer? Das japanische Blockdruck-Genre der awate-e. " M.A. thesis, University of Vienna, 2010

Rotermund, Hartmut O. "Illness Illustrated: Socio-historical Dimensions of Late Edo Measles Pictures (Hashika-e).” In Written Texts - Visual Texts: Woodblock Printed Media in Early Modern Japan, edited by Susanne Formanek and Sepp Linhart. Amsterdam: Hotei Publishing, 2005, pp. 251-282

Satow, Ernest. A Diplomat in Japan. The Inner History of the Critical Years in the Evolution of Japan When the Ports Were Opened and the Monarchy Restored. Berkeley: Stone Bridge Press , 2006 [Stone Bridge Classics]

Schwan, Friedrich B. Handbuch japanischer Holzschnitte. Hintergründe, Techniken, Themen und Motive. Munich: Iudicium, 2003

WDB (Institute of East Asian Studies Vienna University). Ukiyo `e-Karikaturen 1842-1905. 2006, FWF database, www.univie.ac.at/karikaturen, accessed September 2011

Yoshida Teruji 吉田映二. Ukiyo-e Jiten 1 浮世絵辞典 上巻 [Woodblock Print Encyclopedia 1]. Tōkyō: Gabundō, 1972

Yuasa Yoshiko 湯浅淑子. “Bakumatsu no fūshiga ni miru aratame in” 幕末の諷刺画に見る改印 [Censor's Seals seen in the Caricatures of the Bakumatsu Era]. In Bakumatsu no füshiga: Boshin sensō o chūshin $n i$ 幕末の風刺画・戊辰戦争を中心に [Caricatures of the Bakumatsu: Focusing on the Boshin War], edited by Machida Shiritsu Hakubutsukan 町田市立博 物館. Tōkyō: Machida Shiritsu Hakubutsukan, 1995, pp. 74-78 


\section{GLOSSARY}

\begin{tabular}{|c|c|}
\hline awate-e & 慌て絵 \\
\hline bakufu & 幕府 \\
\hline Bakumatsu & 幕末 \\
\hline banzuke & 番付 \\
\hline bokashi & ぼかし \\
\hline boshin-sensō-e & 戊辰戦争絵 \\
\hline daimyō & 大名 \\
\hline dokyō & 度胸 \\
\hline Edo & 江戸 \\
\hline Edokko & 江戸っ子 \\
\hline fukusha & 福者 \\
\hline fūshiga & 風刺画 \\
\hline gai(koku)jin & 外(国)人 \\
\hline haikai & 俳諧 \\
\hline han & 藩 \\
\hline hashika-e & 麻疹絵 \\
\hline Hodogaya & 保土ケ谷 \\
\hline ijin & 異人 \\
\hline inaka & 田舎 \\
\hline Ise & 伊勢 \\
\hline$j \bar{o} i$ & 攘言 \\
\hline
\end{tabular}

hysteria pictures (nishiki-e genre from 1863)

the Shōgun government

'End of the Shogunate', the last decade leading up to the Meiji restoration (1853-1867)

tabular text format used mainly to display sumō

rankings

colour gradient, a technique in woodblock printing

nishiki-e about the Boshin war

lord of a fiefdom in feudal Japan, vassal of the

Shōgun and the Tennō

courage

the old name of the city of Tōkyō until 1868

'children of Edo', people who had lived in Edo for several generations

lucky person; in awate-e used for a person of wealth woodblock prints caricaturing actual, current events; foreigner, that is, somebody not from Japan; in awate$e$ meaning specifically Britons, or in general Europeans and Americans

a kind of Japanese poetry;

feudal Japan was divided into han (feudal domains)

officially owned by the Tennō/Shōgun and administered by a daimyō and his family, e.g., Satsuma han nishiki-e dealing with the measles epidemic in Edo in 1862 (see, e.g., Rotermund 2005)

a village on the Tokaidō road, in today's Hodogaya district of Yokohama prefecture stranger; in awate-e used for non-Japanese foreigners, specifically Britons and in extension all Europeans and Americans

'The countryside' as opposed to 'the city'; an ancient province, now a city in the Mie prefecture where the famous Ise Shinto shrine is located Abbreviation for sonnō jōi (literal translation: 'Revere the emperor, expel the barbarians'); the political slogan and name of a movement with the goal to overthrow the shogunate and reinstate the emperor; a xenophobic orientation supported by the emperor, which led to several attacks on foreigners, among them the Namamugi incident;

Kagoshima＼cjkstart鹿児島 a city in the south of Kyūshū island, Japan; in the Edo period is was the capital of the Satsuma domain kanemochi 金持 rich person; verbatim: money owner; the term of choice in Japan today 


$\begin{array}{ll}\text { kawaraban } & \text { 瓦版 } \\ \text { ken } & \text { 拳 } \\ \text { ken no e } & \text { 拳の絵 } \\ \text { kubihiki } & \text { 首引き } \\ \text { machibure } & \text { 町触 } \\ \text { manji } & \text { 政 }\end{array}$

Meiji ishin 明治維新

$\begin{array}{ll}\text { Meiji-jidai } & \text { 明治時代 } \\ \text { mitate-e } & \text { 見立絵 }\end{array}$

mochimaru 持丸

$\begin{array}{ll}\begin{array}{ll}\text { monomochi } \\ \text { Namamugi jiken }\end{array} & \begin{array}{l}\text { ものもち } \\ \text { 生麦事件 }\end{array} \\ \text { namazu-e } & \text { 鯰絵 } \\ \text { ni-mai-tsuzuki } & \text { 二枚続 } \\ \text { nishiki-e } & \text { 錦絵 } \\ & \\ \text { rashamen } & \text { らしやめん } \\ \text { Sakoku } & \text { 鎖国 }\end{array}$

news publications carrying information about current events, often printed in black and white only; sold by yomiuri, who read the text out loud or sang about the events in the publications, often accompanied by a shamisen, to advertise their goods (see, e.g., Brandl 2009, Groemer 1994, Linhart 2005a, Nagura 2007) Japanese drinking game with many variants, the most popular variant depicted in ukiyo-e being fox-ken (with fox, village head and hunter); the variant rockpaper-scissors is well known in the West; ken-picture; a picture depicting a ken-game (see above)

'neck-pulling', a tug of war with the neck; a common trial of strength in medieval Japan

An official bulletin to bring orders from the government to the city population in the Edo era; counter-clockwise swastika, a symbol of Buddhism, used today for marking Buddhist temples in maps Meiji Restoration (1866-1868); revolutionaries claiming allegiance to the Tennō won against the supporters of the reigning Shōgun government; the position of Shōgun was abolished and the Tennō restored as the official head of state of Japan (without much gain of power on the part of the Tennō)

Meiji era (1868-1912)

a picture of parodic allusion, showing, for example, children at play representing fighting warriors, or a person in the guise of a god rich person; sometimes 持o using an actual circle instead of the character for 'circle'; the inversion marumoch $i$ 丸持 with the same meaning also appears in awate-e; obsolete rich person; verbatim: owner of things; obsolete Namamugi incident, named after the village of Namamugi nishiki-e about the Ansei earthquake in Edo in 1855 ('catfish pictures') woodblock print consisting of two slips of paper multicoloured woodblock prints, called 'Brocade pictures' because of their many-coloured beauty similar to brocade cloth

Japanese prostitute for foreigners a time of Japanese national isolation, when only limited trade with foreign nations was allowed via the island of Dejima in the harbour of Yokohama; the restrictions were relaxed over time and under pressure from foreign governments 


\begin{tabular}{|c|c|c|}
\hline Satsuei-sensō & 薩英戦争 & $\begin{array}{l}\text { the so-called Anglo-Satsuma War was an attack of } \\
\text { British war ships on Kagoshima, the capital of the } \\
\text { Satsuma-han in } 1863\end{array}$ \\
\hline Satsuma-han & 薩摩藩 & $\begin{array}{l}\text { The Satsuma domain was a mighty domain in Edo- } \\
\text { period Japan, headed by the Shimazu family }\end{array}$ \\
\hline shaku & 笏 & $\begin{array}{l}\text { flat wooden or ivory baton carried in the right hand } \\
\text { by noble men in formal attire and Shinto priests }\end{array}$ \\
\hline shamisen & 三味線 & $\begin{array}{l}\text { A three-string musical instrument played with a } \\
\text { plectrum (bachi), typical of Geishas in the Edo } \\
\text { period; }\end{array}$ \\
\hline shinbun nishiki-e & 新聞錦絵 & $\begin{array}{l}\text { woodblock print newspapers (also 錦絵新聞, see } \\
\text { Linhart 2005b) }\end{array}$ \\
\hline Shitamachi & 下町 & urban area of Edo \\
\hline Shōgun & 将軍 & $\begin{array}{l}\text { the head of the Japanese government from the } 12 \text { th } \\
\text { century CE until the Meiji restoration, when the } \\
\text { emperor (Tennō) was reinstated as the official head of } \\
\text { state, replacing the Shōgun (the actual meaning of the } \\
\text { word Shōgun is 'general') }\end{array}$ \\
\hline Tennō & 天皇 & emperor of Japan \\
\hline tōjin & 唐人 & $\begin{array}{l}\text { foreigner; verbatim 'Chinese person', but referring to } \\
\text { all other foreigners as well (also written as とう人) }\end{array}$ \\
\hline Tōkaidō & 東海道 & $\begin{array}{l}\text { the Tōkaidō road ran along the coast connecting the } \\
\text { capitals of Edo and Kyōto and was the most important } \\
\text { travel route and most famous road in Edo-period } \\
\text { Japan. There are many woodblock prints showing } \\
\text { parts of it, most famously several series depicting all } \\
\text { posting houses along the road. }\end{array}$ \\
\hline Tsurumi district & 鶴見区 & $\begin{array}{l}\text { a district of the city of Yokohama in Kanagawa } \\
\text { prefecture }\end{array}$ \\
\hline tsuzura & 葛籠 & $\begin{array}{l}\text { a large rectangular basket used for transporting } \\
\text { clothes }\end{array}$ \\
\hline ukiyo & 浮世 & $\begin{array}{l}\text { floating world; world of pleasures; the pleasure } \\
\text { quarters }\end{array}$ \\
\hline ukiyo-e & 浮世絵 & Japanese woodblock prints \\
\hline Uraga & 浦賀 & $\begin{array}{l}\text { harbour city at the entrance to the Bay of Edo/Tōkyō; } \\
\text { today, part of the city of Yokosuka in Kanagawa } \\
\text { prefecture }\end{array}$ \\
\hline Utagawa Kuniyoshi & 歌川 国芳 & $\begin{array}{l}\text { taken to be the initiator of the caricature boom; his } \\
\text { students probably designed several of the awate-e }\end{array}$ \\
\hline warumono & わるもの & bad/evil person; in awate-e used as a code-word for \\
\hline $\begin{array}{l}\text { Yamanote } \\
\text { yomiuri }\end{array}$ & $\begin{array}{l}\text { 山の手 } \\
\text { 読売 }\end{array}$ & $\begin{array}{l}\text { Westerners, specifically the British } \\
\text { the hinterland of Edo north and west of the castle } \\
\text { news-teller; sold kawaraban by singing about the } \\
\text { current events they contained }\end{array}$ \\
\hline Yoshiwara & 吉原 & the pleasure quarters of Edo \\
\hline
\end{tabular}

